Max-Planck-Institut für demografische Forschung

Max Planck Institute for Demographic Research

Konrad-Zuse-Strasse $1 \cdot$ D-18057 Rostock · GERMANY

Tel +49 (0) 3812081 - 0; Fax +49 (0) 3812081 - 202;

http://www.demogr.mpg.de

MPIDR WORKING PAPER WP 2008-007

FEBRUARY 2008

\title{
Education and permanent \\ childlessness: Austria vs. Sweden; a research note
}

Gerda Neyer (neyer@demogr.mpg.de)

Jan M. Hoem (hoem@demogr.mpg.de)

(C) Copyright is held by the authors.

Working papers of the Max Planck Institute for Demographic Research receive only limited review. Views or opinions expressed in working papers are attributable to the authors and do not necessarily reflect those of the Institute. 



\title{
Education and permanent childlessness: Austria vs. Sweden; a research note
}

\author{
by Gerda Neyer and Jan M. Hoem ${ }^{1}$
}

To appear in the book

"Demographic Challenges for the 21st Century. A Tribute to the Continuing Endeavours of Prof. Dr. Em. Ron Lesthaeghe in the Field of Demography",

edited by Johan Surkyn, Jan Van Bavel and Patrick Deboosere, with contributions also by Frans Willekens, Alberto Palloni, Vladimir Shkolnikov, Tomas Sobotka, Michel Poulain, Aart Liefbroer, and Emily Grundy.

VUB/Academia Press, Bruxelles (2008)

\begin{abstract}
In this research note we extend our previous study of the association between educational attainment and permanent childlessness in Sweden (Hoem et al., 2006) to cover Austria, and we make comparisons between the two countries. In both investigations we have defined educational attainment in terms of both educational level and educational field. We find largely the same pattern of childlessness by educational field in both countries; in particular at each educational level women educated for teaching jobs or for health occupations typically have lower childlessness than other lines of education. However, for most groups childlessness is higher in Austria, and for academic educations it is much higher. We attribute these differences to institutional differences in the two countries which may bring about a different culture of reproductive behavior.
\end{abstract}

Acknowledgement: We are grateful to Adelheid Bauer and Josef Kytir of Statistics Austria for preparing the data for us, to Kathrin Teschner for programming support, and to Gunnar Andersson for insightful comments. 


\section{Introduction and descriptive summary}

In all European countries fertility levels have declined in recent decades, often to well below the replacement level. Low fertility levels and the rising share of women among individuals with a higher education have generated a lot of interest in the relationship between education and permanent childlessness. In the German-speaking countries this interest has been further nurtured by estimates of forty or more percent childlessness among highly educated women (Dorbritz 2003). Even if subsequent studies find somewhat lower levels than this (e.g. Schmitt and Winkelmann 2005, Duschek and Wirth 2005, Scharein and Unger 2005), they confirm the observation that in Germany permanent childlessness is considerably higher among women with an academic education than among other women. ${ }^{2}$

In a recent paper based on Swedish data, Hoem, Neyer, and Andersson (2006) demonstrated that the association between educational attainment and childlessness can be much less straightforward than this. They found that while childlessness largely does increase with educational level, the increase is not very strong in their data. Moreover, the differences in childlessness by educational level diminish over the life-course so that in the case of Sweden, highly educated women in their forties have the same level of childlessness as less highly educated women of the same age (Neyer, Hoem, and Andersson 2007). There are, however, pronounced differentials in childlessness by educational field. Hoem, Neyer, and Andersson (2006) find that in Sweden the field of education is more important than the educational level. Swedish women educated for jobs in teaching and health care have much lower permanent childlessness at each educational level than any other major educational grouping. By contrast, women educated in arts and humanities or for religious occupations have unusually high percentages permanently childless. The pattern seems to be similar in Norway (Lappegård and Rønsen 2005).

Hoem, Neyer, and Andersson (2006) point out several features which could produce the pattern they find: the structure and flexibility of the educational system, the differences in the labor-market and employment conditions for different educational groups, the gender patterns in education and in the labor market, and social norms and preferences linked to education and childbearing. An obvious question is whether these patterns of childlessness are unique to the Scandinavian type of society or whether they extend to countries with different educational systems, different labor-market structures, and different welfare-state setups. Comparing the patterns of different countries would allow us to better assess the interlinkages between institutional, cultural, and individual factors in shaping childbearing behavior.

In the present paper we focus on childlessness in Austria, a country that shares some features with Sweden, but differs markedly in others. As in our Swedish study, we make use of individual-level data of women born between 1955 and 1959, grouped into some sixty educational categories defined by field and level of education. We observe the share of childless among these women at an age when most of them have completed childbearing, namely at age 41 to 46 .

Our main findings are twofold: First, the Austrian pattern of childlessness by educational field is very similar to the one found for Sweden, with women educated

\footnotetext{
${ }^{2}$ Due to the lack of reliable statistics in Germany the level of permanent childlessness can only be approximated (Kreyenfeld 2004).
} 
for teaching and health having lower levels of childlessness than most others on each educational level. Second, Austria differs markedly from Sweden with regard to the differentials in childlessness by educational level. Contrary to Sweden, Austrian women with a secondary or tertiary education have much higher childlessness than women with lower educational attainment. These differences and similarities between the two countries seem to underline the importance of institutional factors in shaping childbearing decisions. It seems that such factors influence individual and cultural factors, such as preferences and social norms, and thus set the frame for the different patterns of childbearing behavior across Europe.

In the following Section 2 we outline some of the institutional and cultural features of Austria that may be relevant for childbearing, and we present the main characteristics of the educational system in Section 3. We describe our data and present the core results of our exploration in Section 4. In the final section of our paper we sum up our explanations for the Austrian pattern of childlessness and its differences from the Swedish pattern.

\section{Austria - a country of educational and social conservatism}

Austria and Sweden share a sufficient number of features to make them interesting cases for comparison. Both countries are small welfare states of approximately the same population size ( 8 to 9 million people). Both countries have coordinated market economies. They are considered to offer a high degree of employment protection and of skill protection due to the dominant role of organizations like trade unions and employers' associations in labor-market policies, social policy, and vocationaltraining policies (Hall and Soskice 2001; Soskice 2005; Estévez-Abe, Iversen, and Soskice 2001; Estévez-Abe 2005; Pontusson 2000). During the 1970s Sweden served as a model for the Austrian government in its endeavor to modernize Austrian society and the Austrian welfare state (Hoem, Prskawetz, and Neyer 2001, 250).

However, and despite this endeavor, Austria and Sweden have taken markedly different paths regarding their educational systems, their welfare-state setups, their parental-leave and childcare policies, and their gender- and social-equality policies. Sweden is commonly regarded as the prototype of a universal welfare state with a commitment to enabling mothers to participate in the labor market and to enhancing gender and social equality; Austria on the other hand represents a conservative, gendering welfare state which supports mothers' absence from the labor market and which does not strive actively to reduce gender and social inequality. (For an overview over the policies of both countries covering the decades relevant for our cohort, see Hoem, Prskawetz, and Neyer 2001.)

Austrian welfare-state policies have maintained class- and gender-related social differences (Esping-Andersen 1990; 2002). Parental-leave policies, introduced in the late 1950s, have supported mothers' absence from the labor market through comparatively long, rather inflexible parental leaves of one to three years duration ${ }^{3}$, which, until 1990, were exclusively reserved for mothers, i.e., fathers were not

\footnotetext{
${ }^{3}$ In our description we focus on the period relevant to our cohort (between the 1960s and 2000). Details of the policies can be found in Hoem, Prskawetz, and Neyer 2001.
} 
entitled to parental leave. Childcare facilities for children under age three and afterschool arrangements for school children are rare. Labor-market policies have given priority to protecting the rights of employees rather than to increasing female employment and to reducing the gender gaps in employment, job positions, pay, or care (Biffl 1997). Gender-equality policies have not been institutionalized consistently, and Austria is still a less (gender) egalitarian society than Sweden.

\section{The Austrian educational system and its differences from the Swedish} system

The class- and gender-differentiating orientation of Austrian society is also mirrored in its educational system. Like Sweden ${ }^{4}$, Austria started to reform its educational system in the early 1960s. Until then, it was characterized by three features: (i) the influence of the Catholic Church in educational matters, (ii) gender segregation in education (no co-educational classes wherever possible), and (iii) the dual system of vocational education, with vocational schools mainly organized through the general educational system and apprenticeships dominated by the social partnership (corporatist) institutions. ${ }^{5}$ A reform of the school system in 1962 and subsequent amendments aimed at increasing the general level of education in the population and making it easier to change between educational tracks. However, Austria did not develop a comprehensive school system as Sweden did, but maintained early separation of pupils into different tracks of education. It continued to offer the dual system of vocational schools and apprenticeships; and it stuck to women-specific lines of education or curricula well into the 1980s.

The Austrian educational system is split into an array of different types of schools, which may themselves be subdivided into a number of lines of education. Despite attempts to coordinate the various curricula, there exist strong differences in teaching requirements and achievement expectations, and these differences hamper moves between the various types of schools or educational lines. The following description provides an overview over the Austrian educational system during the years in which our five-year cohort passed through education, see Figure 1. We only sketch the main educational tracks relevant for our study of childlessness, and we present the tracks in their hierarchical order.

\footnotetext{
${ }^{4}$ See Hoem, Neyer, and Andersson 2006 for a description of the Swedish system.

${ }^{5}$ For a history of the Austrian educational system after 1945 and in particular during the period relevant for our cohort, see Engelbrecht 1988, 485ff.
} 
Figure 1: Austrian educational system

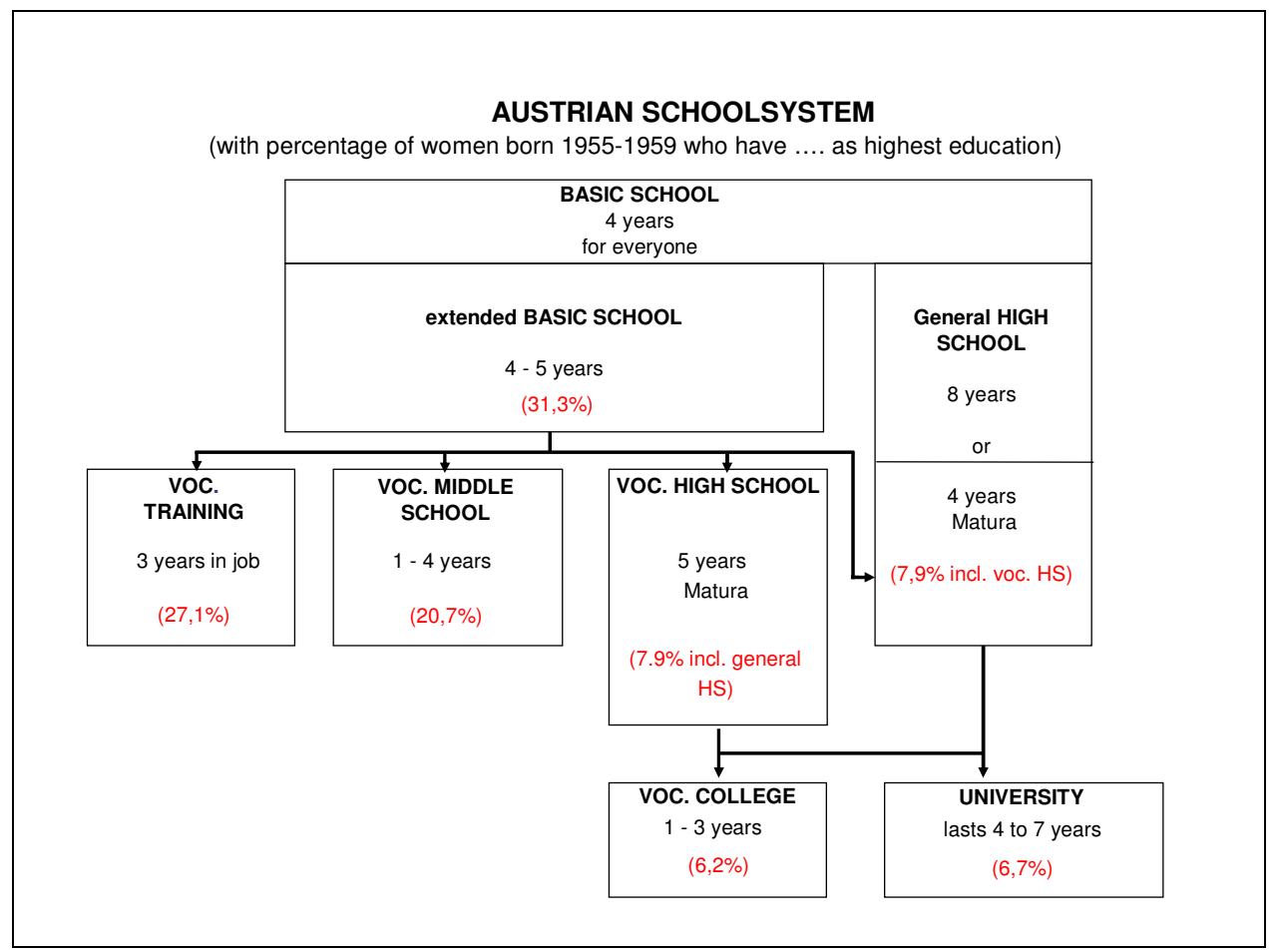

Primary school (Level 1). In Austria, all children go to basic school ("Volksschule") for four years. After four years (at age 10), pupils are separated into those who continue in basic school ("Hauptschule") and those who prepare for entry into general high school ("Allgemeinbildende höhere Schule") (Level 4).

Pupils who continue in basic school ("Hauptschule") go on for another four years. Subsequently (at age 14) they can transfer to another type of school (see below: Level 3, Level 4) or move to apprenticeships in vocational training (Level 2). If they do not continue schooling in another type of school or in an apprenticeship, they must take a fifth year of basic schooling ("Polytechnischer Lehrgang") to complete nine years of compulsory education. In our cohort, some $31 \%$ of the women left the school system through this route.

Vocational training (Level 2) usually lasts for three years (from age 14 to 17 or so). The training is given through apprenticeships and is provided on the job. Pupils go to school ("Berufsschule") only one or two days a week. More than three hundred professions are taught in this way, but women are usually concentrated in education for a narrow range of professions (sales, textile production, hair-dressing, or work in hotels and restaurants). Some $27 \%$ of the women of our cohort ended their education at this level.

Vocational middle school (Level 3) lasts for one to four years. This type of school offers professional training in office work, technical drawing, nursing, social work, home economics, household administration, hotel- and restaurant activities, farming, and so on. In our cohort, almost $21 \%$ of the women left school at this level.

General high school (Level 4) has two levels, namely the lower general high school (for pupils aged 10 to 14) and the upper general high school (for pupils aged 15 to 18). The lower-level part offers a general curriculum during the first two years. 
Thereafter (i.e., at the age of 12) pupils must select an orientation (streaming). The main differentiation lies between (i) a line more oriented toward languages, (ii) a line more oriented toward mathematics and natural sciences, and (iii) a line oriented toward (home-) economics. The latter line has been particularly aimed at women.

Vocational high school (also Level 4) usually lasts for five years (from age 14 to 19) and thus is one year longer than (upper) general high school. In addition to the theoretical education of general high schools, vocational high schools provide educations for specific occupations, such as any technical profession (including technicians below the tertiary level), industrial professions (e.g., for the textile industry), work in business and administration, and so on. In our grouping of educational attainment we have combined vocational high school with general high school on Level 4, but we have maintained the educational orientation ("general" for "general high school" and the respective fields for women who completed a vocational high school). In our cohorts, almost $8 \%$ ended up with high school (general or vocational taken together) as their highest level of education.

All high schools end with the "maturation examination" (called "Matura"). ${ }^{6}$ It confers the right to enter institutions of higher education and opens up higher-echelon career tracks in the civil service that are not available to persons who have not taken the Matura. The Matura is the watershed that divides educational groups into people with and people without the possibility for higher education. It is the entrance to higher social status.

Vocational college (Level 5) can be entered by women and men who have completed high school (i.e., who have the Matura). It usually lasts for one or two years (sometimes for three years) and offers professional training in specific fields, e.g. to become a teacher for schools below high school, a medical technician, a social worker, a professional in commerce and trade, in tourism, in advertising activities, and so on. In our cohorts, some $6 \%$ ended up with vocational college.

University (Level 6) studies $^{7}$ were supposed to last mostly for four years for a degree (Magisterium ${ }^{8}$; Diploma; Doctorate). On average, students have needed longer than this, however, and getting a university degree usually has taken seven to eight years of study (Dell'Mour and Landler 2001). ${ }^{9}$ In our cohorts, almost $7 \%$ of the women completed a university-level education.

There are some striking general differences between the Austrian and Swedish educational systems. First, Austria separates its pupils into different streams at a much earlier age than Sweden does. While in Sweden all pupils pass through a nine-year comprehensive school up to the age of 16 and most pupils continue further to lower-

\footnotetext{
6 This corresponds to the German "Abitur", the French "baccalauréat", or the Swedish "studentexamen" and corresponding examinations in the other Nordic countries ("examen artium" and so on).

${ }^{7}$ We count institutions called "Universitäten" and "Hochschulen" to institutions at this level.

${ }^{8}$ This is the Austrian designation for a degree on the master level.

${ }^{9}$ During the time when most women of our cohort went through academic education, bachelor's degrees did not exist. Furthermore, one did not necessarily need a Magisterium to take a doctorate. Some lines (such as law and medicine) did not offer separate master and doctorate studies, but everyone who completed these lines was awarded a doctorate. In cases where a magisterium/diploma was a pre-requisite for a doctorate, students needed another two to four years of study on average.
} 
or upper-secondary (two- and three-years) high school ${ }^{10}$, Austria separates its pupils into different educational tracks after 4 years of school already (at age 10) and again after four further years (at age 14).

Second, the Austrian system of vocational apprenticeship is segregated from the general school system, while in Sweden vocational training is largely offered within the general high-school system (in our case, mostly as two-year tracks). The Austrian training system via apprenticeships offers much less general education than the Swedish system does (Lassnigg 2006; Culpepper 2007). It thus provides less "portable" skills, and this is assumed to make job changes more difficult (EstévezAbe et al 2001).

Third, the Swedish system of comprehensive and integrated education at the primary and secondary level facilitates changes in educational fields as pupils pass through their studies. It is furthermore set up to offer all women and men the opportunity to enter higher education and/or to make up for missed education later in life. By contrast, the organization of the Austrian school and apprenticeship system makes changes in educational choices rather difficult. During the time when most women of our cohort received their education, changes between different types of schools or lines of education (below college and university level) were hampered by differences in curricula, grade requirements, or age limits. Access to higher (academic) education has been restricted mainly to those who have passed the Matura. At all levels of education (below college and university) the possibilities to make up for missed education or training are limited, not least due to age restrictions regarding participation in public education and training.

Fourth, the Swedish system of education provides substantial opportunities to re-enter, re-train, upgrade, or complement educational attainment throughout the life course. The Austrian system, by contrast, is much more closed. Opportunities to interrupt and subsequently re-enter the educational system are rare (and almost impossible below university level), and possibilities to re-train or refresh previous training are not readily available. Active labor-market policies which support (re)training in case of job loss or employment interruption have also been much more developed and widely available in Sweden than in Austria, narrowing Austrian women's possibilities to maintain their "educational capital" or adjust their education to their child caring needs.

Finally, the Swedish school system has as a goal to support gender and social equality in education and training (Erikson and Jonsson 1996). Austria, even though it shares the same goals in principle, nevertheless adhered to women-specific educational lines and programs well through the period when our cohort went to school (Engelbrecht 1988, 479ff.; Brehmer and Simon 1997, 318-324; Mikula 1997) and the organization of its school system has made it even more difficult than in Sweden to reduce social-class differences in educational participation and educational attainment. In summary the Austrian educational system is much more prone to channel pupils into specific educational tracks; it is much more rigid regarding educational participation and educational careers; and it offers much fewer

\footnotetext{
${ }^{10}$ Two- and three-year lines of upper secondary education existed when the cohort of women born between 1955 and 1959 went to school. The two-year lines have later been extended to three-year lines.
} 
possibilities to re-arrange one's education according to one's changing interests and family needs. Such features cannot fail to influence childbearing.

\section{Data and Main Results}

Our empirical analysis is based on individual-level data from the Austrian census of 2001. The cohort of 1955-1959 comprises about 297.000 women. This matches the size of the cohort of our Swedish study (about 250.000 women). It contains the highest education attained by each census member, coded into about 650 educational groups. Using the international standard classification of education (ISCED classification of 1997) we have re-coded these groups into some sixty more comprehensive educational lines, further summarized into seven main educational fields. The educational lines and fields correspond largely to the educational groups which we used in our Swedish study. ${ }^{11}$ The classification of the educational levels follows the structure of the Austrian school system described above. Due to the differences between the Austrian and the Swedish educational system, the Austrian levels of education do not correspond entirely to the levels which we used in our Swedish study. In particular, the Austrian separation between vocational training as apprenticeship and vocational middle school does not exist as such in the Swedish system, where, as we mentioned above, vocational training is provided in the comprehensive school. Furthermore, the Austrian data do not allow us to differentiate between women who have an education at the master's level and women who have a doctorate as their highest degree, as was possible in our Swedish study (Hoem, Neyer and Andersson 2006). These differences in organization need to be taken into account when we compare childlessness by education of Austrian and Swedish women.

\subsection{Educational field and childlessness}

As we mentioned in our introduction, two results of our investigation are striking. First, Austria and Sweden display a largely similar pattern of childlessness by educational field (see Figure 2 and Figure 2a below). In both countries, women trained to be teachers or for a health occupation have lower childlessness than most others at each educational level. They often have lower childlessness than women educated in other fields at a lower educational level. For example, Austrian ${ }^{12}$ primary school teachers $(16.5 \%$ childless), who have passed through a vocational college, have lower childlessness than women with an apprenticeship as beautician (17.8\%), as sales personnel in insurance, banking and travel (18.7\%), as book sellers $(25.7 \%)$, or women who have finished general high school (22.9\%) or a vocational high school for tourism $(24.2 \%)$ or for textile, chemistry, computer work, and the like (22.9\%). Likewise, "only" a quarter of female physicians are permanently childless in our study of Austria, which is about the same as women with a much briefer training for professions in tourism or as booksellers (Figure 2 below and Table 1 on page 12).

\footnotetext{
${ }^{11}$ Some educations are provided in Sweden but not in Austria (such as the education of librarians and police personnel) and vice versa (like the education in tourism in Austria). We have included specifically Austrian educations here if they are noteworthy for the understanding of childlessness and if they comprise a sufficiently large number of women.

${ }^{12}$ We report mainly the Austrian findings here and use selected findings for Sweden for comparison only. For further details on Sweden, see Hoem, Neyer, and Andersson 2006.
} 
At the other end of the spectrum, Austrian women trained in the social sciences, journalism, art, theology, and humanities have very high percentages childless (about one-third). Women trained as teachers in art, theology, or humanities have lower childlessness than those have completed the same field of study, but without teaching qualifications. This is similar to the situation in Sweden. In both countries, it seems that teachers who specialize in humanities, arts, or music remain childless more often than those who specialize in, say, the natural sciences or economics. Childlessness is also higher among women who have an education close to humanities and arts, such as booksellers (Austria) or librarians (Sweden). In Austria there are some groups of women with a university degree in the arts or humanities who display exceptionally high levels of childlessness, like art historians (45.6\%), women who studied theatre production or theatre as a science $(47 \%)$, women with a degree in painting, graphics, and design (39.8\%) and historians $(40,0 \%) .{ }^{13}$ The childlessness among these women reaches levels that signal that a life without children is a common life-pattern for them.

\footnotetext{
${ }^{13}$ We do not display them separately in our diagram, where we only show the field of education, not the subject a woman specialized in. However, there are sufficient numbers of women with the specific specialization mentioned to consider them in the text.
} 


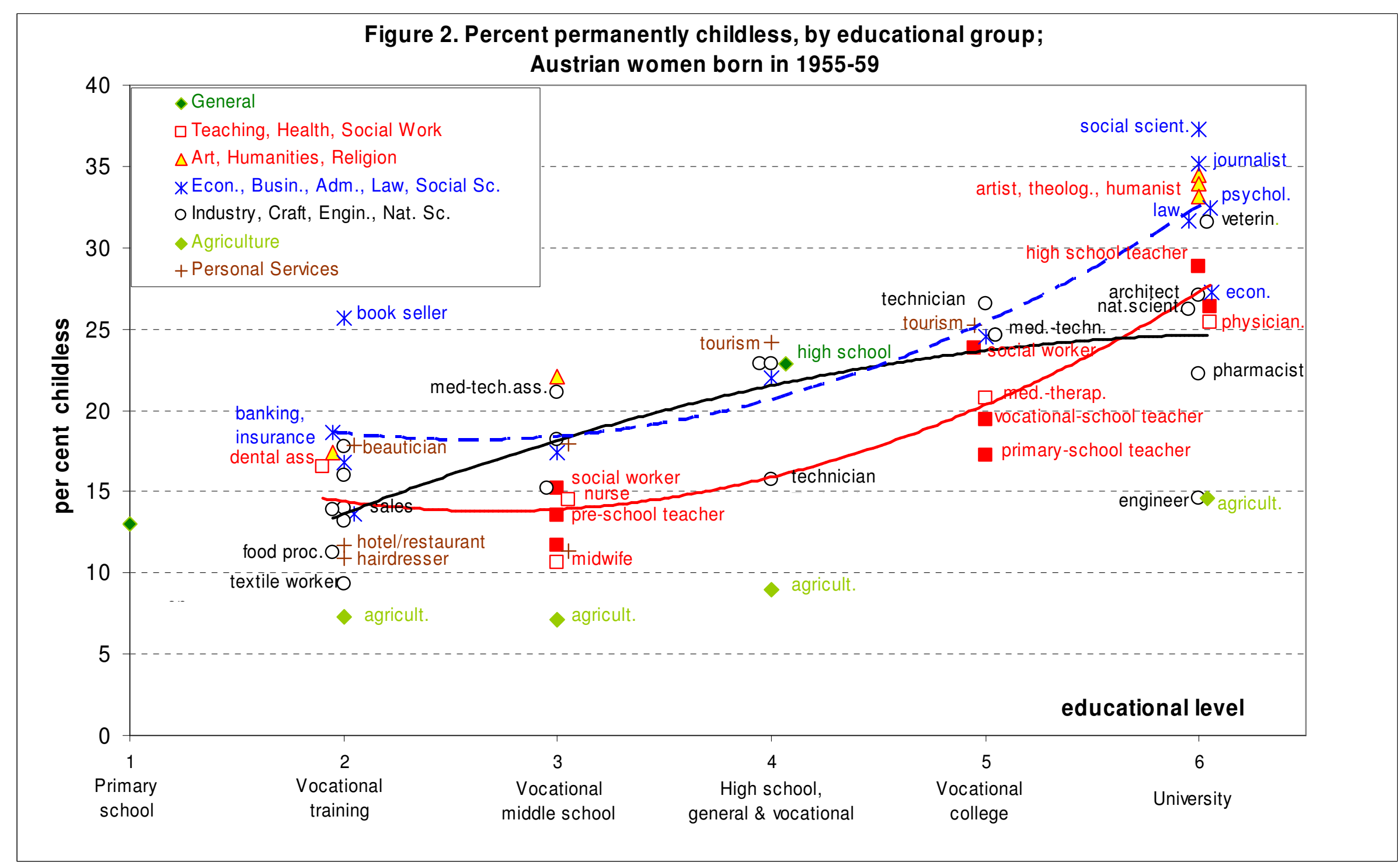

Note: The curvilinear descriptive trendlines in the diagram are intended to facilitate spotting its patterns. We have restricted ourselves to trendlines for the most extensive types of education. The red trendline relates to educations in health and teaching; the black trendline to education for professions in industry, craft, engineering, natural and technical science; the blue trendline to economics, business, administration, law and the social sciences. 


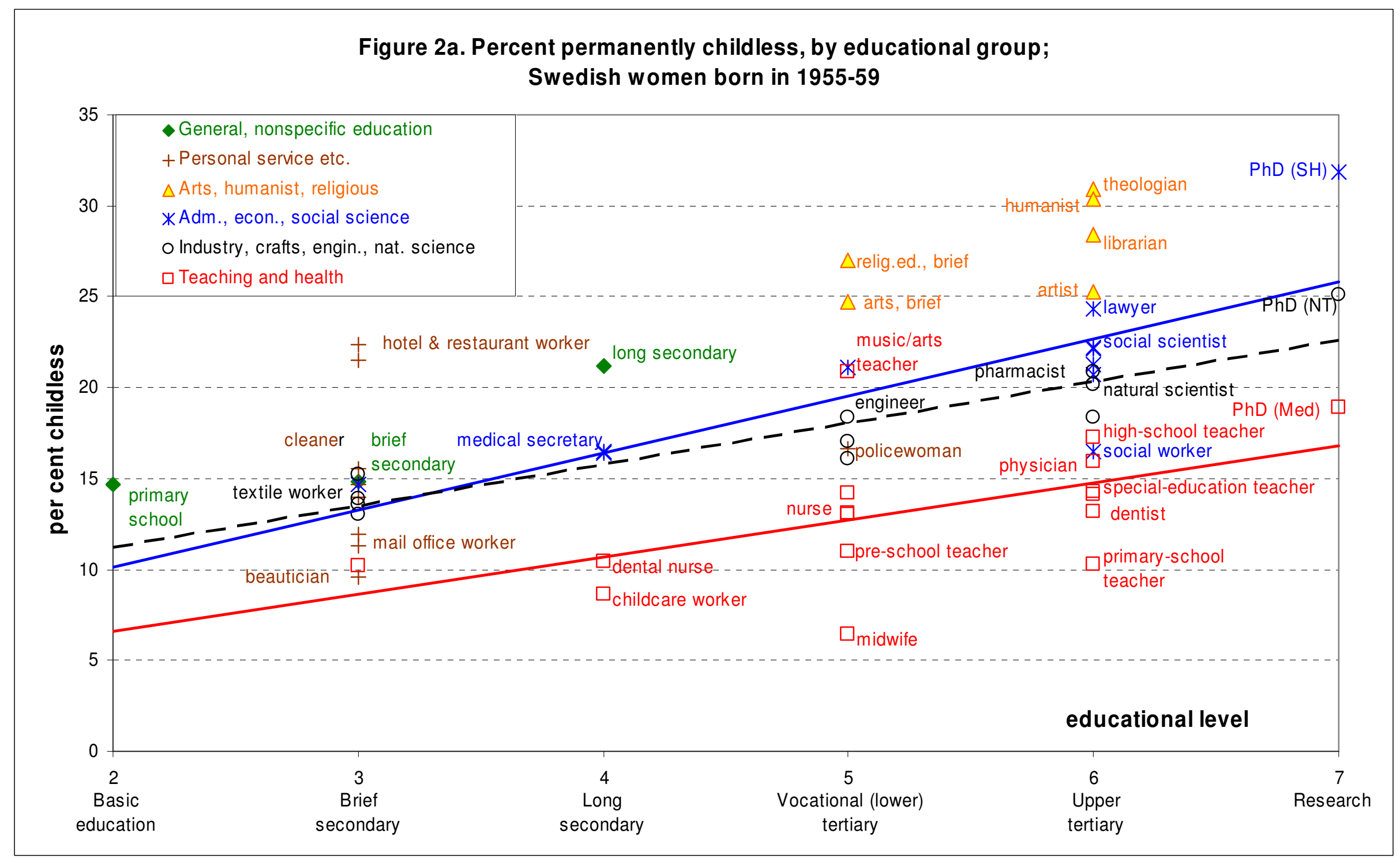

Source: Hoem, Neyer, and Andersson 2006 


\subsection{Educational level and childlessness}

Our second main finding concerns childlessness by educational level in Sweden and in Austria. Two results are remarkable: Both countries have the same level of overall childlessness, namely $15.7 \%$. But Austria and Sweden differ markedly with regard to the childlessness of highly educated women: In each group Austrian women with an upper-secondary or higher education have much the higher childlessness than Swedish women do (Figure 3).

\section{Figure3: Childlessness by Level of Education}

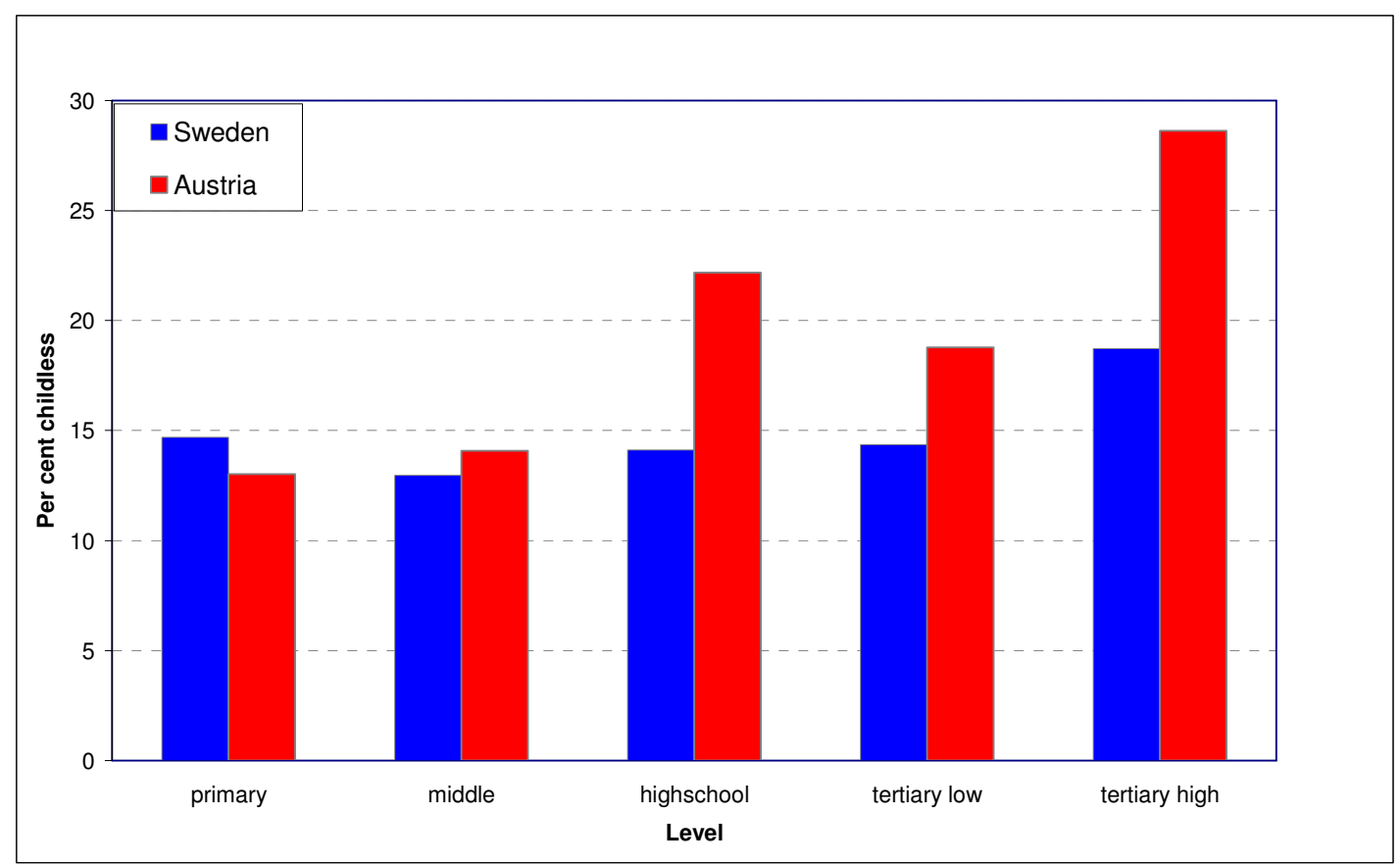

Note:

Austria: primary: basic school (up to age 15)

middle: apprenticeship; vocational middle school

high school: general or vocational high school

tertiary low: vocational college

tertiary high: university

Sweden: primary: comprehensive school (up to age 16)

middle: two-year secondary school

high-school: three-year secondary school

tertiary low: vocational college

tertiary high: upper tertiary education and research degrees

In Sweden, there is no real difference in childlessness levels between women with a comprehensive education, a two-year secondary school, a three-year secondary school, and a vocational college or a lower-tertiary education (Figure 3). Only women with an upper-tertiary education (that is a degree at the master's level) or a research degree (doctorate) remain more often childless than others. ${ }^{14}$ In Austria, by contrast, it

${ }^{14}$ The Swedish data allow us to distinguish between women with a master's level education (uppertertiary education) and women with a research degree (doctorate). The latter group has much higher childlessness $(24.5 \%)$ than women on the master's level $(18.5 \%)$. However, the level of childlessness 
is already women with an upper-secondary education ("Matura") who display noticeably higher childlessness than do women with a lower education. Moreover, at each educational level, the discrepancy in childlessness between highly educated women and those with less education is much more pronounced in Austria than in Sweden. Unlike in Sweden, there seems to be a clear division in fertility behavior by educational status in Austria, with the main difference being between those who have finished at least high-school ("Matura") and those who have not.

The difference in childlessness by educational status in Austria is also visible if we compare childlessness among women in the same field but at different levels of education. As an example, Table 1 lists the percent childless among women with an education in teaching and health. In Sweden, women with an education in these fields have notably lower childlessness than women in any other field of education, as we have mentioned already. Austrian women with such educations have higher childlessness than the Swedes at all educational levels, but the really strong difference lies between those who have a university degree and those who do not. Compared to Swedish women, but also compared to Austrian women with the same field of education attained at an institution below the university level, Austrian women with a university education in teaching or health have some ten percentage points higher childlessness (see Table 1, Figure 2, and Figure 2a).

Similar differences in childlessness by educational level can be found for other fields of education, such as textile, leather, and fashion production, hotel work and tourism, and social work. In all these educations childlessness increases from about $10 \%$ for educations taken as apprenticeship to about $15 \%$ to $18 \%$ if the woman went to a middle school, and to about $25 \%$ for those who took the education in a vocational high-school or a vocational college (see Figure 2).

among women with a Ph.D. is still lower than the level of childlessness among Austrian women with a university degree (28.6\%). Since we cannot differentiate between these upper levels in our Austrian data, we only present the share of childlessness among women with a university degree in Figure 3. 
Table 1. Per cent childless, by educational level and orientation. Austrian and Swedish women born in 1955-59

Teachers

pre-school teacher primary-school teacher high-school teacher

\section{Health personnel}

midwife

nurse

physician

\section{Below "Matura"}

beautician, hairdresser

textile worker

apprenticeship vocational school

hotel and restaurant worker apprenticeship vocational school

agricultural work
Austria

13.5

16.5

29.1

10.6

14.5

25.4

12.7

10.6

9.3

15.2

12.7

11.7

17.9

7.4
Sweden

11.0

10.3

17.3

6.4

13.0

15.9

$\underline{\text { University-level outliers }}$

journalist

35.0

social scientist ${ }^{15}$

37.3

33.9

22.4

theologian

34.5

33.1

32.5

31.6

15.5

humanist (non-teach.)

psychologist

veterinary

30.9

25.3

30.4

32.7

$22.0^{16}$

\begin{tabular}{lcr} 
Engineers and natural scientists (university level) \\
\hline engineer & 14.6 & 19.0 \\
natural scientist & 26.2 & 22.0
\end{tabular}

\subsection{Childlessness among women without "Matura"}

At the basic and lower secondary levels the two national systems are sufficiently different to make it difficult to compare educational groups directly. For most groups, rather low levels of education are mostly associated with low levels of childlessness in both countries. For Austria, we furthermore find that childlessness increases somewhat with the educational level. On average, women who learned their profession through training in an apprenticeship have lower childlessness than women

\footnotetext{
${ }^{15}$ Sociologist, political scientist, anthropologist.

${ }^{16}$ Agronomists and veterinaries taken together.
} 
who received their training in the same profession in a vocational middle school (see examples above). This result, as well as a comparison between different professions, suggests that childlessness increases with the social status of the education or of the profession it leads to.

Compared to Sweden, some results are surprising: Austrian women educated to be hotel and restaurant workers have much lower childlessness $(11.7 \%$ for an apprentice; $17.9 \%$ for vocational school) than their Swedish counterparts (22.4\%). In Sweden, this group is taken as typical of educations that lead to occupations with long and odd working hours and high employment mobility, for which reasons one would expect much childlessness (Hoem, Neyer, and Andersson, 2006, Section 5.2.2). The Austrian counterexample seems to show that such explanations need not be sufficient. The fact that there are about fourteen times as many women with an apprenticeship or vocational training for the hotel, restaurant and tourist sector in Austria than in Sweden, that the vast majority of employees in this sector work in (their own) family businesses, and that the hotel, restaurant and tourist sector has a high share of seasonal workers, may provide elements of a further explanation. It may be that the structure of the business (small/large; seasonal/non-seasonal; family business/non-relative employer) has a bearing on childbearing behavior. If so, the differences in business structure between Austria and Sweden (Katzenstein 1988; Culpepper 2007) may account for some of the differences in childlessness we find for specific educational fields. However, viewed across all educational fields the findings are not conclusive.

Swedish women with an education for the agricultural sector have much higher childlessness (15.5\%) than women with a similar education in Austria (about $7 \%$ for both apprenticeship and vocational agricultural school). The same applies to women with an agricultural education at higher educational levels. Compared to childlessness among women in general, Austrian women with an education for the agricultural sector have unusually low percentages permanently childless (Figure 2). We suspect that there may be a strong component of tradition in this finding, in that educations of this nature are more likely to be taken by women with an agricultural background, many of whom will eventually enter or take over their family business. Moreover, vocational agricultural schools are often located in agricultural regions and may provide the only further education available in the region. These schools also offer a broad spectrum of education covering all areas necessary for running an agricultural business, including areas considered useful for women, such as housekeeping, food processing, and nutrition. These factors may explain why among our cohorts there are almost three times as many Austrian women who finished an education in agriculture (through apprenticeship or vocational school) than there are Swedish women with such an education.

\subsection{University-level outliers}

The fourth panel in Table 1 lists a number of educations that have unusually high percentages childless in both countries, but particularly in Austria, where these educational groups almost invariably have higher childlessness than corresponding groups in Sweden.

In Austria, women educated as engineers constitute a group that deviate in the opposite direction (see the fifth panel in Table 1). Their childlessness (15\%) is lower than that of all other academic groups (except female agronomists) and below that of 
many groups with much less education. Women who went to a vocational high-school with a focus on technical engineering or construction also have lower childlessness than women with an education from a general high-school or a vocational high school with a different focus (Figure 2). We would have expected both groups of women with an engineering degree to have childlessness on the level of natural scientists. However, there are much fewer women who take a technical education than women who take an education in the natural sciences, at all levels of education. Women with a technical education are trained to work in highly masculine professions. It may be that women find the working conditions and the career options in such occupations so unfavorable that they turn to other pursuits than engineering and that they are less inclined to forgo motherhood for a career than women with an education that leads to less unfavorable working conditions. ${ }^{17}$ Studies also indicate that women who choose a technical education more often have highly educated parents (Fischer-Kowalski 1985). It is possible that highly educated women who come from a highly educated family background may have less difficulty than other women in combining work and childbearing.

Veterinaries, who are often coded as having an agricultural education, similarly deviate from the general pattern of childlessness among women with an agricultural education. They have much higher childlessness than women with an academic degree in agriculture, and they even range among the academically trained women with particularly high levels of childlessness (such as women trained in law or psychology; see Figure 2 and Table 1). Almost one-third of female veterinaries remain childless. Why veterinaries should be so different, is open to speculation. As a brief review of the current specialization of female veterinaries shows, their professional activity is not so often connected to farm animals but rather to domestic pets in an urban environment. The vast majority of veterinary are self-employed, and this may lead to a higher share of childlessness. .

\section{Reflections}

As we have outlined in the introduction and in our previous paper (Hoem, Neyer, and Andersson, 2006), patterns of childlessness are bound to reflect several institutional, cultural, and individual factors: the structure and organization of the educational system, the conditions on the labor marked that women encounter when they have completed their education, the gender patterns in education and occupation, the gendering or de-gendering of the welfare state and of public policies, as well as social norms and preferences. Correspondingly, the patterns of childlessness in Austria and Sweden may reflect similarities and differences between the systems and thus in the opportunities and constraints for women regarding education, work, and childrearing in the two countries. Since our data do not allow us to investigate childbearing behavior in detail, we restrict ourselves to sketching some of the differentials that might produce the patterns we have found.

\footnotetext{
${ }^{17}$ Studies of the 1980s showed that many women who chose technical (and male) dominated professions left these more often than women in other professions (Pelz, Spitzy, and Wagner 1983).
} 
As we spelled out above, Austria has an educational system that is much more segregated by gender and by social class, and that is relatively inflexible, while Sweden has a comprehensive, more egalitarian, and flexible system. Though both countries have aimed at increasing the share of women (and men) in higher education, in our cohort Austrian women who get a higher education are still a select group. The differences to Sweden are striking: Only 13\% of the Austrian women in our cohort got a tertiary education (vocational college or university); the figure for Sweden is $33 \%$. The share of women with the highest (university level) educational attainment was twice as large in Sweden (12.1\%) as in Austria (6.7\%). Among Austrian women $79 \%$ did not complete an education with high-school level ("Matura"), which compares with 53\% in Sweden. Almost twice as many Austrian women (31\%) as Swedish women $(16 \%)$ had no more than basic education. The fact that Austrian women with a high school ("Matura") or a higher degree constitute such a small minority in our cohort may contribute to the high share of childlessness among women with higher education in Austria. Having a high education offers employment possibilities which are not accessible to others, and it may well be that women with such opportunities do not want to endanger them through childbearing. This may also explain the increase in childlessness by educational level below high school and the higher childlessness among women with an education in a field that offers access to occupations with higher social status (e.g.: white-collar rather than blue-collar jobs). In both cases, childlessness may be due both to the scarce opportunities to re-enter the educational system once one has left it, and to the problems of interrupting employment for childbearing and childrearing. The latter issue may lead to a depreciation of educational capital and the risk of having to subsequently accept employment below one's educational and thus social status.

Contrary to Sweden, Austrian educational, labor-market, welfare-state, and family policies do not counter such depreciation sufficiently. Parental-leave and childcare policies in Austria support mothers' absence from the labor market rather than their employment, while Sweden does the opposite (Hoem and Hoem 1997, Hoem at al. 2001). The attitude that mothers should primarily devote their lives to their children is still common in Austria, where three-quarters of the people hold the view that a pre-school child is likely to suffer if his or her mother works (Halman 2001, 141). By comparison, only half as many Swedes (38\%) share this opinion.

In addition to centering family policies on motherhood, Austria has also policies less firmly oriented toward gender equality than Sweden has. When our Austrian cohort passed through the educational system, even co-education was not fully established. Almost a third of all women in high school and more than half of all women in vocational middle schools or in apprenticeships were in a predominantly ${ }^{18}$ female school or line of education and had curricula with a gendered content. In particular, programs specifically addressing women as mothers and housewives were still in place (Fischer-Kowalski et al. 1985; Lassnigg and Paseka 1997). Such education may have been out of step with the orientation of (many) women and may have aroused resistance to motherhood, particularly during the 1970s and 1980s, when feminist debates about motherhood as a gate to discrimination of women were part of the public and political discourse in Austria.

Women in Austria concentrate on a rather narrow range of educational fields, and the fraction of women is high in particular employment areas and jobs. The

${ }^{18}$ A line with at least $95 \%$ females. 
pattern is similar in Sweden, but this country has managed to reduce gender differentials in employment and in care much more than Austria has. Researchers assume that gender inequality in the workplace (and also in the household) may account for low fertility and may produce high childlessness (McDonald 2000; Neyer 2003). As regards the workplace the high childlessness among Austrian women with a tertiary education that leads to employment in the public sector (teaching in high school; law) may reflect such features.

Regulations protecting parenthood for public-sector employees are in place in both countries, and, as is the case among Swedish women, one would expect to find lower childlessness among Austrian women with an education that leads to employment in the public sector. In Austria, too, the public sector offers tenure and much better employment protection than the private sector does; it has a more egalitarian wage structure than the private sector, and it used to offer longer parental leaves than the private sector did. However, tenure was usually dependent on continual employment (seniority) and full-time employment, both of which may be forfeited in the case of childbearing. A study from 1993 revealed that $60 \%$ of the female employees in the Austrian public sector lacked tenure, while only $20 \%$ of the men were in such a situation (Seidl 1993, cit. by Hofmeister 1995). It may well be that inequalities of this character affect childbearing decisions and lead to a higher share of childlessness among women with specific educations. Conversely, the fact of higher childlessness in an educational group may in turn influence attitudes towards childlessness and childbearing in general in a self-reinforcing spiral that may lead to the group-specific patterns of childlessness indicated in Figure $1 .{ }^{19}$

In summary, our Swedish-Austrian comparison of the patterns of childlessness among women with different educational fields and levels underlines the delicate balance between institutional contexts and individual childbearing decisions. Although some similarities in the level of childlessness among women with similar educations in Sweden and Austria suggest that preferences regarding education and childbearing determine fertility behavior (as in the case of women with an education in humanities and art), other results do not support such an interpretation (as in the case of women who opt for a technical education). It seems that the structure of the educational system, the labor market, the welfare state, and the social and gender system are important determinants of fertility patterns, and that they constitute much more than the factual conditions for education and childbearing. They also set the realm for the ideational orientation of a society, an element central to the individual, to whom this article is dedicated.

\section{References}

Biffl, G. (1997). Schule - Wirtschaft - Frauen. In L. Lassnigg, and A. Paseka, (Eds.), Zum Geschlechterverhältnis im Bildungswesen (pp. 234-249). Innsbruck: Studien-Verlag.

Brehmer, I. and Simon, G. (eds.) (1997). Geschichte der Frauenbildung und Mädchenerziehung in Österreich. Graz: Leykam.

\footnotetext{
${ }^{19}$ See also Hoem, Neyer, and Andersson 2006.
} 
Culpepper, P. D. (2007). Small States and Skill Specificity. Austria, Switzerland, and Interemployer Cleavages in Coordinated Capitalism. Comparative Political Studies, 40, 611-637.

Dell'Mour, R., and Landler F. (2001). Determinanten des Studienerfolgs. Projektbericht des Bundesministeriums für Bildung, Wissenschaft und Kultur. Wien.

Dobritz, J. (2003). Polarisierung versus Vielfalt - Lebensformen und Kinderlosigkeit in Deutschland - eine Auswertung des Mikrozensus. Zeitschrift für Bevölkerungswissenschaft, 28(2-4), 403-421.

Duschek, K.-J., and Wirth H. (2005). Kinderlosigkeit von Frauen im Spiegel des Mikrozensus. Eine Kohortenanalyse der Mikrozensen 1987-2003. Wirtschaft und Statistik, 2005(8), 800-820.

Engelbrecht, H. (1988). Geschichte des österreichischen Bildungswesens. Bd. 5: Von 1918 bis zur Gegenwart. Wien: Österreichischer Bundesverlag.

Erikson, R. and Jonsson, J. O. (eds.) (1996). Can Education Be Equalized? The Swedish Case in Comparative Perspective. Boulder: Westview Press.

Esping-Andersen, G. (1990). The Three Worlds of Welfare Capitalism. Princeton: Princeton University Press.

Esping-Andersen, G. (2002). A New Gender Contract. In: G. Esping-Andersen with D. Gallie, A. Hemerijck, and J. Myles: Why We Need a New Welfare State (pp. 68-95). Oxford: Oxford University Press.

Estévez-Abe, M., Iversen T., and Soskice D. (2001). Social Protection and the Formation of Skills. A Reinterpretation of the Welfare State. In: P. Hall, and D. Soskice (Eds.): Varieties of Capitalism: The Institutional Foundation of Comparative Advantage (pp. 143-183). Oxford: Oxford University Press.

Estévez-Abe, M. (2005). Gender Bias in Skills and Social Policies: The Varieties of Capitalism Perspective on Sex Segregation. Social Politics 12(2), 180-215.

Fischer-Kowalski, M. et al (1985). Bildung. Bericht über die Situation der Frau in Österreich. Frauenbericht 1985(2). Wien: Bundeskanzleramt.

Hall, P. and Soskice D. (Eds) (2001). Varieties of Capitalism: The Institutional Foundation of Comparative Advantage. Oxford: Oxford University Press.

Halman, L. (2001). The European Values Study: A Third Wave. Source Book of the 1999/2000 European Values Study Survey. Tilburg University: WORC.

Hoem, B., and Hoem J. M. (1997). Sweden's family policies and roller-coaster fertility. Journal of Population Problems (Tokyo), 52(3-4), 1-22.

Hoem, J. M., Prskawetz, A, and Neyer, G. (2001). Autonomy or conservative adjustment? The effect of public policies and educational attainment on third births in Austria. Population Studies, 55(3), 249-261. Reprinted in the Vienna Yearbook of Population Research, 2003, 101-119.

Hoem, J. M., Neyer, G., and Andersson, G. (2006). Education and childlessness: The relationship between educational field, educational level, and childlessness among Swedish women born in 1955-59. Demographic Research, 14(15), 331-380. Available: http://www.demographic-research.org/Volumes/ Vol14/15/14-15.pdf . 
Hofmeister, L. (1995). Der männliche Geschlechtsvorzug im österreichischen Bundesdienst. In: U. Floßmann (Ed.), Feministische Jurisprudenz: Blicke und Skizzen (pp. 69-90). Linz: Universitätsverlag R. Trauner.

Kreyenfeld, M. (2004). Politikdiskussion fehlt verlässliche statistische Grundlage. Demografische Forschung aus Erster Hand, 1(3), 4.

Lappegård, T., and Rønsen, M. (2005). The multifaceted impact of education on entry into motherhood. European Journal of Population, 21, 31-49.

Lassnigg, L. (2006). Forschungsfragen zur Zukunft der dualen Ausbildung in Österreich. Vienna: Institute for Advanced Studies.

Lassnigg, L. and Paseka A. (1997) (Eds.). Zum Geschlechterverhältnis im Bildungswesen. Innsbruck: Studien-Verlag.

McDonald, P. (2000). Gender equity, social institutions and the future of fertility. Journal of Population Research 17(1), 1-16.

Mikula, R. (1997). "Die Verweiblichung der Buben und eine Vermännlichung der Mädchen”. Die Koedukationsdebatte im 20. Jahrhundert. In: I. Brehmer, and G. Simon (Eds.): Geschichte der Frauenbildung und Mädchenerziehung in Österreich (pp. 235-260). Graz: Leykam.

Neyer, G. (2003). Family policies and low fertility in Western Europe. MPIDR working paper WP 21. Rostock. Max Planck Institute for Demographic Research. Available: http://www.demogr.mpg.de/papers/working/wp-2003021.pdf

Neyer, G., Hoem, J. M., and Andersson, G. (2007). Kinderlosigkeit, Bildungsrichtung und Bildungsniveau. Ergebnisse einer Untersuchung schwedischer Frauen der Geburtenjahrgänge 1955-59. In: D. Konietzka, and M. Kreyenfeld (Eds.): Ein Leben ohne Kinder. Kinderlosigkeit in Deutschland (pp. 105-134). Wiesbaden: Verlag für Sozialwissenschaften.

OECD (1999). Classifying Educational Programmes. Manual for ISCED-97; Implementation in OECD Countries. Paris: OECD Publishing.

Pelz, M., Spitzy Ch., and Wagner I. (1983). Mit technischem Verstand. Mädchen in nicht-traditionellen Berufen. Forschungsbericht aus Arbeitsmarkt und Sozialpolitik 4. Wien: Bundesministerium für soziale Verwaltung.

Pontusson, J. (2000). Labor Market Institutions and Wage Distribution. In: T. Iversen, J. Pontusson and D. Soskice, (Eds.), Employment and Central Banks. Macroeconomic Coordination and Institutional Change in Social Market Economies (pp. 292-330). Cambridge: Cambridge University Press.

Scharein, M., and Unger, R. (2005). Kinderlosigkeit bei Akademikerinnen? Die Aussagekraft empirischer Daten zur Kinderlosigkeit bei Akademikerinnen. BiB-Mitteilungen, 26(2), 6-13.

Schmitt, C., and Winkelmann, U. (2005). Wer bleibt kinderlos? Was sozialstrukturelle Daten über Kinderlosigkeit bei Frauen und Männern verraten. Feministische Studien, 23(1), 9-23.

Seidl, M. (1993). Einkommensunterschiede zwischen Männern und Frauen im Bundesdienst. Diploma thesis. Vienna: Economics University. 
Soskice, D. (2005). Varieties of Capitalism and Cross-National Gender Differences. Social Politics, 12(2), 170-179.

Statistics Sweden (1996). Svensk utbildningsnomenklatur, Del 1. Systematisk version. Meddelanden i samordningsfrågor 1996, 1. 